\title{
Antiviral Activity of Liquorice Powder Extract against Varicella Zoster Virus Isolated from Egyptian Patients
}

\author{
Rania I. Shebl, MSc; Magdy A. Amin' 1 PhD; Amal Emad-Eldin' ${ }^{1}$ PhD; \\ Saad M. Bin Dajem², PhD; Amal S. Mostafa ${ }^{3}, \mathrm{PhD}$; \\ Essam H. Ibrahim ${ }^{2,4}$ PhD; Aly F. Mohamed, PhD
}

Background: Varicella-zoster virus (VZV) is the etiologic agent of two diseases, varicella (chicken pox) and zoster (shingles). Varicella is a self- limited infection, while zoster is mainly a disease of adults. The present study was conducted to isolate VZV from clinically diagnosed children using cell cultures and compare the activity of liquorice powder extract, an alternative herbal antiviral agent, with acyclovir and interferon alpha $2 \mathrm{a}(\mathrm{IFN}-\alpha 2 \mathrm{a})$ against the isolated virus.

Methods: Forty-eight VZV specimens, 26 from vesicular aspirates and 22 from vesicular swabs, from children clinically diagnosed with varicella were isolated on the Vero cell line. Isolates were propagated and identified with specific antiserum using indirect immunofluorescence and immunodot blotting assays. The growth kinetics of the viral isolates was studied. The antiviral activity of liquorice powder extract, acyclovir (ACV) and IFN- $\alpha 2 \mathrm{a}$ was evaluated against the isolated virus.

Results: $\quad$ VZV was successfully isolated in 4 of the 48 specimens, all from vesicular aspirates. The growth kinetics of the viral isolates was time dependent. The inhibitory activity of liquorice powder extract (containing $125 \mu \mathrm{g} / \mathrm{ml}$ glycyrrhizin) when compared to ACV $(250 \mu \mathrm{g} / \mathrm{ml})$ and IFN- $\alpha 2 \mathrm{a}$ is the lowest.

Conclusions: VZV isolates were successfully isolated and propagated using Vero cells. Isolates were identified using indirect immunofluorescent and immunodot blotting techniques. Growth kinetics of the isolates revealed an increase in the viral infectivity titer relative to time. Glycyrrhizin in the crude form has low antiviral activity against VZV compared with acyclovir and interferon.

(Chang Gung Med J 2012;35:231-9)

Key words: varicella-zoster virus, antiviral agents, immunofluorescence, virus isolation, immunodot

$\mathrm{V}$ aricella-zoster virus (VZV) is one of the human herpes viruses belonging to the alphaherpesvirinae subfamily of herpesviridae. ${ }^{(1)}$ VZV causes chick- enpox, a common disease in children that is characterized by a vesicular rash accompanied by fever. Following the primary infection, the virus establishes

From the Holding Company for Biological Products and Vaccines (VACSERA), Cairo, Egypt; ${ }^{1}$ Department of Microbiology and Immunology, Faculty of Pharmacy, Cairo University, Cairo, Egypt; ${ }^{2}$ Biology Department, Faculty of Science, King Khalid University, Abha, Saudi Arabia; ${ }^{3}$ Viral Vaccines Quality Control and Research Department; ${ }^{4}$ Blood Products Quality Control and Research Department, National Organization for Research and Control of Biologicals, Cairo, Egypt.

Received: Mar. 29, 2011; Accepted: Oct. 25, 2011

Correspondence to: Dr. Essam H. Ibrahim, Biology Department, Faculty of Science, King Khalid University, Abha, Saudi Arabia; Blood Products Quality Control and Research Department, National Organization for Research and Control of Biologcal, Cairo, Egypt. Tel: 009-66072418606; Fax: 009-66072418608; E-mail: essamebrahim@ @otmail.com 
a lifelong latent infection and is reactivated in adulthood to cause shingles (zoster). It is usually a selflimiting illness, but may be complicated by secondary bacterial skin infection, pneumonitis and encephalitis. ${ }^{(2)}$ There are increasing numbers of atypical cases of varicella in immunocompromised persons. Strategies for controlling VZV outbreaks and atypical cases of VZV infection require confirmation of the infection and implementation of control measures to prevent further spread of varicella. ${ }^{(3)}$

Laboratory diagnostic techniques for VZV infection include immunofluorescence assay for detection of viral antigen in scraped skin lesions and isolation of VZV using cell culture. Polymerase chain reaction using skin scrapings, vesicular fluid, respiratory secretions and cerebrospinal fluid (CSF) is the method of choice for diagnosis of VZV infection. ${ }^{(4)}$

Difficulties in isolating VZV in cell culture have been discussed in many reports including its slow replication in cell culture, difficulty in preparing high-titer cell- free virus, instability of the virus during extraction and decreased sensitivity of cell lines at higher passage levels. ${ }^{(5-7)}$

Although the results of viral cultures cannot be obtained fast enough to influence clinical decisions, they can confirm the diagnosis of VZV infection made by other methods. Successful isolation of VZV using cell culture in cases of positive testing is a reliable method for proof of the infectious virus. ${ }^{(8)}$

Treatment of primary varicella infection is important in vulnerable populations, such as pregnant women, neonates, adults and immunocompromised individuals, because of the expected risk of complications. Antiviral treatment for herpes zoster is necessary to limit the severity and duration of the disease in both immunocompetent and immunocompromised individuals. ${ }^{(9)}$

Acyclovir, famciclovir, and valacyclovir are antiviral agents licensed for the treatment of VZV infections. ${ }^{(10)}$ However, emerging resistance to acyclovir has been reported in immunocompromised patients, particularly in patients with acquired immunodeficiency syndrome. Emerging resistance to antiviral drugs highlights the importance of testing the susceptibilities of VZV isolates to current therapy. Also, screening the antiviral activity of new antiviral agents is important to establish efficient treatment in cases of resistance to acyclovir and for safer treatment, as in pregnant patients. ${ }^{(11)}$ In the present study we aimed to isolate VZV from clinically diagnosed children using cell culture and to evaluate the antiviral activity of liquorice powder extract as an alternative herbal antiviral agent and compare it with acyclovir and interferon alpha 2 a against the isolated virus.

Liquorice, the root of the Glycyrrhiza glabra L. (Fabaceae) plant species, has been used medicinally for more than 4000 years. ${ }^{(12)}$ The genus glycyrrhiza consists of approximately 30 species, of which six species produce a sweet saponin glycyrrhizic acid (GA). ${ }^{(13)}$ Liquorice is one of the most widely used herbal drugs around the world, being present in most pharmacopoeias of eastern and western countries. ${ }^{(14)}$ These medicinal plants are used as flavorings, sweeteners and herbal medicine, and also for improving health, detoxification and cures for injury. ${ }^{(15)}$ They have been traditionally used for respiratory, gastrointestinal, cardiovascular, genitourinary, eye, and skin disorders, and for their antiviral effects. ${ }^{(16)}$

GA, the most studied active constituent of liquorice, is a sweet-tasting material. The constituent is 50 times sweeter than sugar, and is widely used as a sweetening additive in the food industry. ${ }^{(17)}$ In many countries, GA is used as a major therapeutic agent to treat chronic viral hepatitis and allergic dermatitis. ${ }^{(18)}$ It is also known to have antiinflammation, ${ }^{(19)}$ antiulcer, antihepatotoxic ${ }^{(20)}$ and antivirus activities. ${ }^{(21,22)}$

\section{METHODS}

\section{Specimens}

Vesicular fluids were obtained from immunocompetent children 2- 6 years old with varicella, 2 to 5 days after the onset of skin lesions as recommended previously. ${ }^{(23)}$ Twenty-six specimens were collected by aspirating vesicular fluid using sterile $1 \mathrm{ml}$ syringes (Icopiuma, Italy) containing approximately $0.2 \mathrm{ml}$ Earle's Minimum Essential Medium (EMEM) (Gibco-BRL, Long Island, NY, U.S.A.) as a viral transport medium. The syringes were rinsed immediately with $1 \mathrm{ml}$ of viral transport medium (VTM). Twenty-two specimens were obtained by swabbing the vascular fluid using sterile cotton swabs (Nunc, Rochester, NY, U.S.A.). The tissue in the base of the lesions was squeezed to collect the highly cell-associated VZV. The cotton swab was placed in a sterile screw capped tube (Griener 
BioOne, Nurtingen, Germany) containing $1 \mathrm{ml}$ of VTM. Specimens were filtered through $0.22 \mu \mathrm{m} 1 \mathrm{ml}$ $\Phi$ syringe filter (TPP, and preserved at $-70^{\circ} \mathrm{C}$ (Revco, Thermo Fisher Scientific Inc., U.S.A.) until inoculation.

\section{Isolation of $\mathrm{VZV}$}

VZV was inoculated onto tissue culture flasks (Griener) containing a monolayer of African green monkey cells, Vero cells (American Type Culture Collection City, [ATCC] -clone CCL-81). The flask was incubated at $37^{\circ} \mathrm{C}$ for an adsorption period of $1.5 \mathrm{hr}$ with gentle mixing at $15 \mathrm{~min}$ time intervals for good virus distribution. Maintenance medium containing $0.2 \%$ dimethyl sulfoxide was dispensed to cell culture flasks post adsorption time (E-MEM supplemented with $2 \%$ fetal bovine serum without removing the inoculuma as recommended previously. ${ }^{(23)}$ A negative control of noninfected cells was done in parallel. Cultures were examined daily using an inverted microscope (Hund, Wetzlar, Germany) for detection of the cytopathic effect (CPE). Live attenuated varicella vaccine was propagated on human lung fibroblast cells, MRC-5 (ATCC- clone CCL-171) as a positive control.

\section{Preparation of seed stock of the isolated VZV}

Tissue culture flasks showing a CPE of more than $90 \%$ were subjected to 3 cycles of freezing and thawing for extraction of cell- free and cell-associated virus. The collected virus was reinoculated onto Vero cells for seed stock preparation according to previous reports. ${ }^{24,25)}$

\section{Identification of the isolated virus Preparation of $V Z V$ antiserum}

Preparation of anti-VZV antibodies was carried out according to the method of Takasuka et al. with some modifications. ${ }^{(26)}$ Male Swiss mice were subcutaneously immunized with aluminum hydroxide adsorbed varicella vaccine (GlaxoSmithKline, Bidogicals, Rixensart, Belgium). The collected serum was stored at $-70^{\circ} \mathrm{C}$ until use.

\section{Indirect immunofluorescence staining}

Indirect immunofluorescence staining was carried out according to previous reports ${ }^{(27,28)}$ using 8 chamber lab-tech slides (Nunc) pre-cultured with MRC-5 cells. Varicella vaccine was included as a positive control and noninfected cells as a negative control.

\section{Immunodot blotting staining (Antigen Spot Test)}

Immunodot blotting assay was carried out according to the method of Kaufmann et al. using nitrocellulose membranes (Millipore, Corporation, Billerica, MA, U.S.A.). ${ }^{(29)}$ VZV isolates, with varicella vaccine as a positive control and phosphate buffered saline (PBS)/ Tween as a negative control were spotted on nitrocellulose membranes $(5 \mu \mathrm{l}$ in each circle). After blocking of the paper, adding of both primary and secondary antibodies, color development, the membrane was allowed to air dry and then photographed.

\section{Determination of viral infectivity titer using cell culture}

As in previous reports ${ }^{(25,30)}$ the VZV isolates were serially diluted 10 fold. Each dilution was dispensed as $100 \mu \mathrm{l} /$ well onto precultured Vero cells. Noninfected wells were included as a negative control. Plates were incubated at $37^{\circ} \mathrm{C}$. 7 days post infection and the $50 \%$ endpoint $\left(\mathrm{CCID}_{50}\right)$ was determined according to Reed \& Muench. ${ }^{(31)}$

\section{Growth kinetics of VZV isolates on Vero cells}

Growth kinetics of VZV isolates were monitored according to the method of Grose \& Brunel. ${ }^{(32)}$ A total of $250 \mu \mathrm{l}$ of each VZV isolate was inoculated in seven tissue culture flasks $\left(25-\mathrm{cm}^{2}\right.$ surface area; [TPP]). Samples were processed daily to determine the infectivity titer rise, as indicated above. The growth rate for each isolate was calculated relative to the time interval.

\section{Cytotoxicity}

Lquoric powder was kindly provided by Dr. Mai Selmi (Pharmacognosy Department, the National Organization for Drug Control and Research (NODCAR), Cairo, Egypt). She estimated the glycyrrhizin content using high-performance liquid chromotography. The cytotoxicity of the liquorice powder extract and acyclovir (GlaxoSmithkline) was determined according to the methods of Finter \& Vijayan et al. ${ }^{(33,34)}$ Sterile filtrated liquorice and acyclovir extracts were diluted in E-MEM to a final concentration of $2 \mathrm{mg} / \mathrm{ml}$ and were added to plates containing the Vero cell line. Negative cell culture control was 
included by adding only culture media to vero cell. The cell culture plates were incubated at $37^{\circ} \mathrm{C}$ for 24 hrs. The extract treatment media was discarded. Plates were washed with PBS and fixed using 10\% formalin (BDH, Chemicals Ltd., Poole, England) at $0.1 \mathrm{ml} /$ well for $2 \mathrm{hrs}$ at room temperature as described previously. ${ }^{(35)}$ The fixative was discarded and the plates were stained using $0.3 \%$ crystal violet (Sigma-Aldrich, St. Louis, MO, U.S.A.) for $30 \mathrm{~min}-$ utes at room temperature. Excess dye was removed by water flushing. Stained residual living cells were destained using ethanol-glacial acetic acid (BDH), $50 \%(\mathrm{~V} / \mathrm{V})$ to $0.05 \mathrm{ml} /$ well for 5 minutes. The optical density (OD) was measured using an enzymelinked immunosorbent assay (ELISA) reader (MRX, Dynex Technologies, Chantilly, VA, U.S.A.) at a wave length of $550-570 \mathrm{~nm}$. The mean optical densities of the test and control wells were recorded. The viability percentage was determined according to a previous report $^{(36)}$ as follows:

Number of residual living cells $=(\mathrm{OD}$ of treated cells / OD of untreated cells) $x$ Number of negative control cells $\left(10^{4}\right.$ cells $\left./ 0.1 \mathrm{ml}\right)$.

Percentage viability $=($ Number of residual living cells / Number of negative control cells) X 100 .

\section{Antiviral activity}

Antiviral activities of glycyrrhizin, acyclovir and interferon against VZV isolates were determined according to the method of Harada. ${ }^{(37)}$ Nontoxic concentrations of liquorice powder extract containing $125 \mu \mathrm{g} / \mathrm{ml}$ glycyrrhizin, $250 \mu \mathrm{g} / \mathrm{ml}$ acyclovir and 1000,100 , and $10 \mathrm{ng} / \mathrm{ml}$ interferon were used to treat precultured Vero cells for $24 \mathrm{hrs}$ at $0.1 \mathrm{ml} /$ well. One plate was maintained and left untreated for viral control titration. The VZV isolates were serially diluted 10 fold in E-MEM $\left(10^{-1}-10^{-6}\right)$. Antiviral activity was determined by subtracting the VZV mean titer in treated from that in non treated cells. The difference between the titers refers to the antiviral activity.

The inhibitory concentration $\left(\mathrm{IC}_{50}\right)$ was determined according to the method described by Wutzler. ${ }^{(38)}$ Two fold serially diluted acyclovir was used to treat precultured Vero cells for $24 \mathrm{hrs}$ at 0.1 $\mathrm{ml} /$ well. Plates were inoculated using $10 \mathrm{CCID}_{50}$ of the VZV isolates tested. Positive and negative controls were considered. Seven days post incubation the $\mathrm{IC}_{50}$ of acyclovir was determined as the acyclovir concentration required to reduce the virus -induced cytopathic effect by $50 \%$ compared with the untreated control.

\section{Statistical analysis}

Statistical differences between the virus titers in cells treated with antiviral agents and the titers in nontreated cells were determined using one way ANOVA. Differences were considered significant when the $p$ value was less than 0.05 . The statistical differences between the antiviral activities of each two antiviral agents were determined using Tukey's honestly significant difference test.

\section{RESULTS}

\section{Isolation and identification of $\mathrm{VZV}$}

Four out of 48 specimens showed a CPE on cultured Vero cells. All viral isolates were obtained from vesicular aspirate specimens, while none was obtained from swab specimens. The four isolates showed first cytological changes on the $4^{\text {th }}-7^{\text {th }}$ day post inoculation until the development of a $90 \% \mathrm{CPE}$ on the $12^{\text {th }}-16^{\text {th }}$ day as shown in Fig. 1.

On further passaging, the viral isolates showed a gradually elevated replication activity on Vero cells, where the cytological changes (90\% CPE) could be detected within 2-4 days post viral inoculation (Fig. 2) compared with the negative control (Fig. 3).

On the $5^{\text {th }}$ viral passage, the virus was inoculated in MRC-5 cells. Twenty-four hours post inoculation, the infected cells were stained by immunofluo-

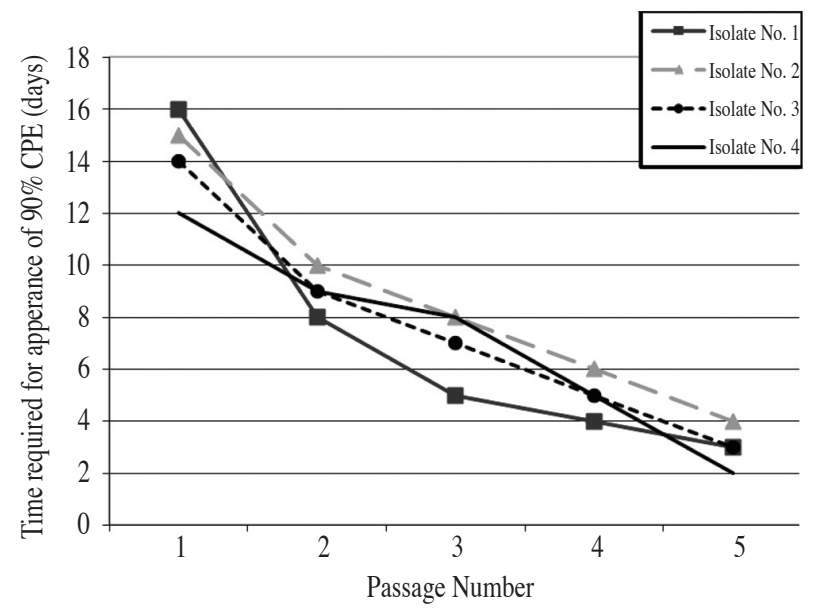

Fig. 1 Correlation between viral passage number and time required for appearance of $90 \%$ cytopathic effects for VZV isolates. 
rescence dye and the virus could be detected in the infected cells as apple green fluorescence (Fig. 4).

VZV isolates were identified using immunodot blot assay, where brown colored spots indicated positive reactivity to the specific antiserum prepared against the reference vaccine (Fig. 5).

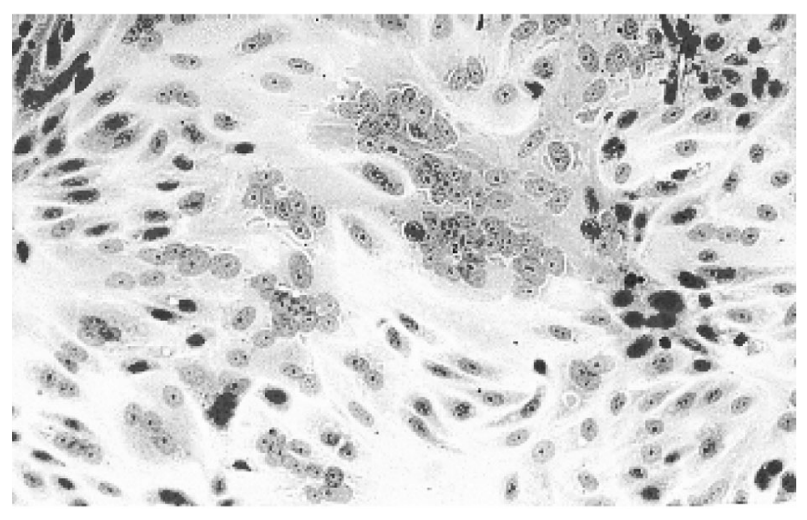

Fig. 2 Cytological changes in the Vero cell line.

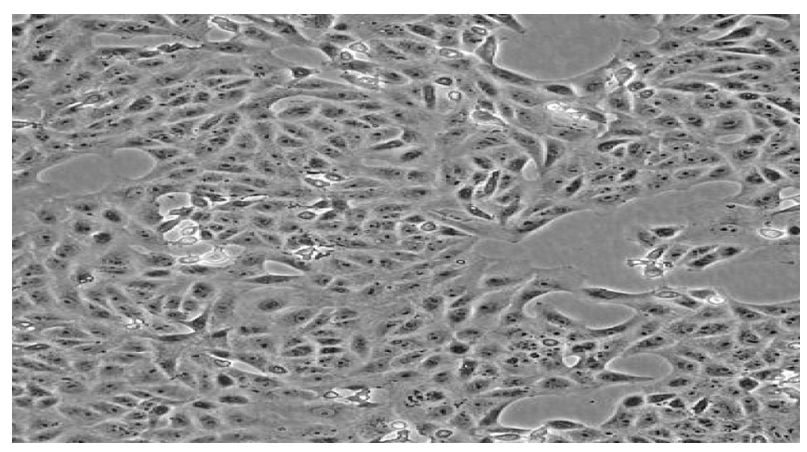

Fig. 3 Negative cell control $48 \mathrm{hr}$ postinoculation. Cells are swollen, refractile and distinct from the transparent cell sheet.

\section{Growth kinetics of the isolated $\mathrm{VZV}$ on Vero cells}

Evaluation of viral isolates growth kinetics on Vero cells indicated a progressive elevated viral infectivity titer relative to time in the order of 0.56 $\log (10) / 24 \mathrm{hr}, 0.4 \log _{(10)} / 24 \mathrm{hr}, 0.429 \log _{(10)} / 24$ $\mathrm{hr}$ and $0.543 \log _{(10)} / 24 \mathrm{hr}$, with viral infectivity titers of $10^{4.5} / 0.1 \mathrm{ml}, 10^{3.8} / 0.1 \mathrm{ml}, 10^{3.5} / 0.1 \mathrm{ml}$ and $10^{5} / 0.1 \mathrm{ml}$ for isolates no.1, 2, 3 and 4, respectively 7 days post inoculation (Fig. 6).

\section{Cytotoxicity}

Evaluation revealed that $125 \mu \mathrm{g} / \mathrm{ml}$ glycyrrhizin and $250 \mu \mathrm{g} / \mathrm{ml}$ acyclovir had no cytotoxic effect on Vero cells (Fig. 7).

\section{Antiviral activity}

Liquorice powder extract containing $125 \mu \mathrm{g} / \mathrm{ml}$ glycyrrhizin showed the least depletion in virus infectivity titer $(0.5 \mathrm{log})$ followed by acyclovir and interferon recording 4 and $5 \log$ decreases, respec-

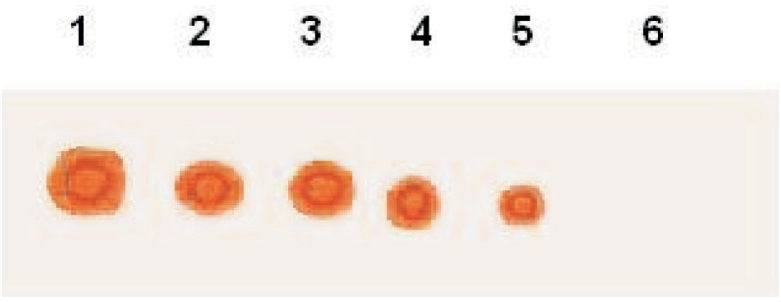

Fig. 5 Identification of VZV isolates by immunodot blotting. (1) positive control, (2) isolate No. 1, (3) isolate No. 2, (4) isolate No. 3, (5) isolate No. 4, and (6) negative control.
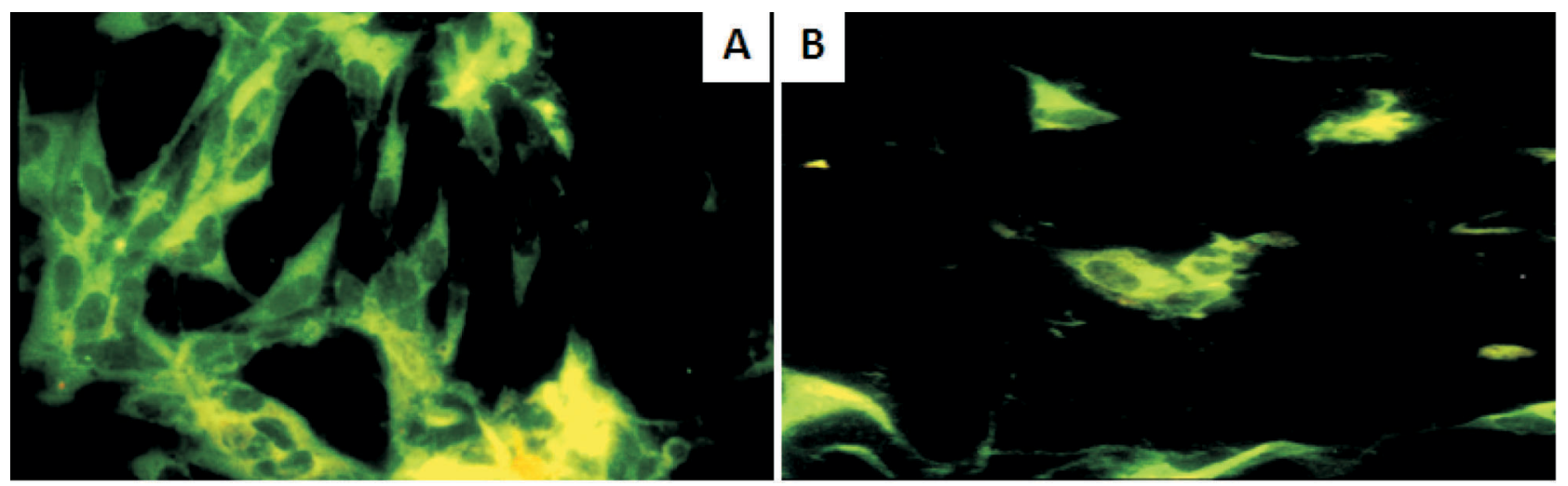

Fig. 4 MRC-5 cells (A) infected with VZV isolate showing apple green fluorescence indicating positive antigen detection for VZV isolates. (B) positive control. 


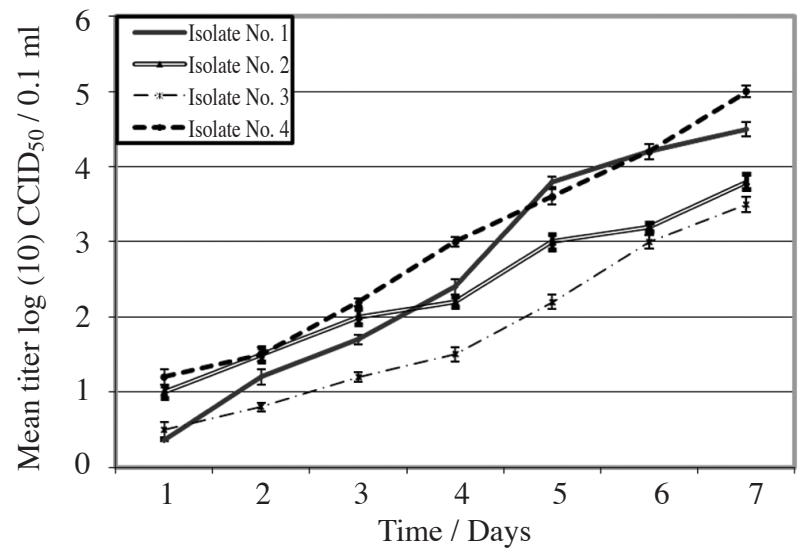

Fig. 6 Evaluation of growth kinetics of VZV isolates on Vero cells relative to time; Error bar: mean $\pm \mathrm{SD}, \mathrm{n}=3$.

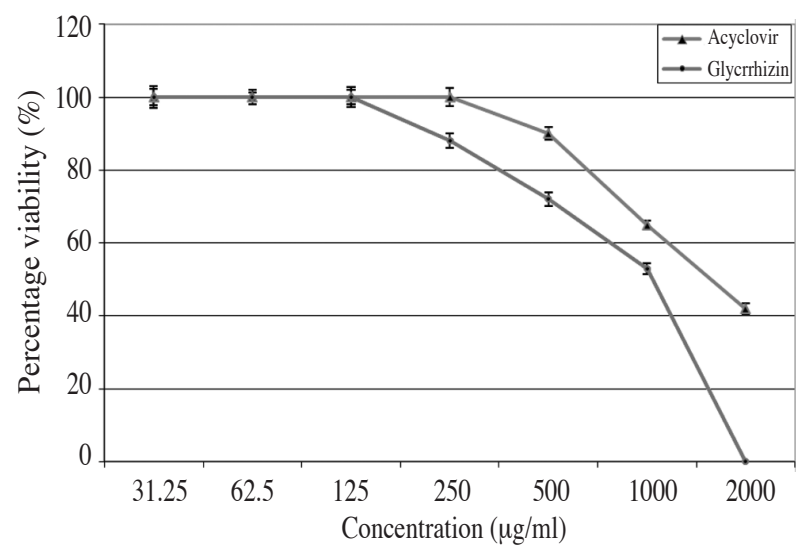

Fig. 7 Evaluation of cytotoxicity of liquorice extract containing glycyrrhizin and acyclovir on Vero cells, Error bar: mean $\pm \mathrm{SD}, \mathrm{n}=3$.

tively. The differences between the mean log virus titers in cells treated with glycyrrhizin, acyclovir and interferon compared with the mean log virus titer in untreated cells were statistically significant using one way ANOVA $(p<0.05)$. On further dilution of acyclovir, the $\mathrm{IC}_{50}$ ) was reached at $7.8 \mu \mathrm{g} / \mathrm{ml}$ (Fig. 8).

\section{DISCUSSION}

Although a reduction in the incidence of chickenpox was reported with the introduction of the varicella vaccine in $1995,{ }^{(39)}$ vaccination against VZV is not a routine policy in many countries and seasonal outbreaks of the wild type infection of the virus continue to occur. In addition, increasing numbers of atypical cases of varicella in immunocompromised

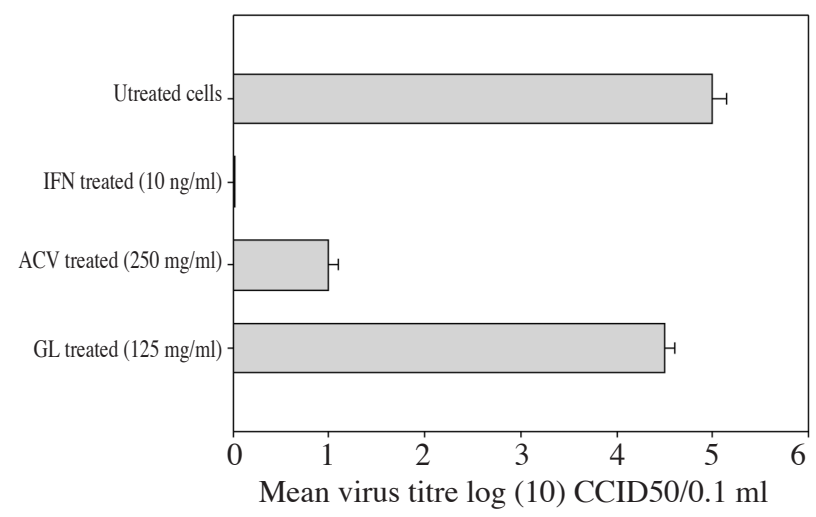

Fig. 8 Evaluation of antiviral activity of liquorice extract containing glycyrrhizin, acyclovir and interferon against VZV isolate No. 4, Error bar: mean $\pm S D, n=3$. The differences between the mean logs were statistically significant using one way ANOVA $(p<0.05)$. Abbreviations used: IFN: interferon$\alpha$; ACV: acyclovir; GL: glycyrrhizin.

persons have also been reported. Isolation and identification of VZV is of great importance in confirming infection and studying the characteristics of the virus, including the viral growth kinetics and susceptibility to different antiviral agents, in order to find an alternative to the current therapy for controlling the severity of the disease.

In the present study, VZV was isolated from the vesicular lesions of immunocompetent children with chicken pox. ${ }^{(40)}$ Other studies reported recovery of VZV from other sites such as as mononuclear cells, $\mathrm{CSF}$, and biopsy specimens during the late incubation period and the acute phase of the disease. VZV has been isolated and propagated on the African green monkey kidney Vero cell line. ${ }^{(23,24,41,42)}$ In the mean time Gerna et al and O'Neill et al. ${ }^{(43,44)}$ reported that human embryonic lung fibroblast cell lines (MRC-5 and WI-38) were sensitive for the detection and isolation of VZV.

Collecting vesicular fluid was more efficient than cotton swab sampling in the present study, and all viral isolates were obtained from vesicular fluid specimens. It has been noted that swabbing is not an effective means to obtain vesicular fluid. ${ }^{(23)}$ The introduction of a cotton swab into a suspension of VZV may reduce the titer 5 fold because of physical binding of the virus to the swab material. Also, Levin et al. reported that toxic substances in the swab inactivated the virus and were toxic to cell cul- 
ture. ${ }^{(45)}$

In the present study, 4 out of 48 collected specimens were positively isolated on the Vero cell line. The low percentage of recovered isolates might be attributed to virus loss because of filtration of specimens prior to inoculation onto Vero cells. Virus loss may be due to the protein binding capacity of the membrane filters, as well as timing of the sample collection, which may be due the time between onset of infection and sample patient admission to hospital. Filtration of specimens using a $(0.45 \mu \mathrm{m})$ filter decreases the chance of success of VZV isolation. ${ }^{(45,46)}$ Also, in this study, the rate of isolation was high in the first 3 days after the onset of the disease but, it declined gradually with time.

The delayed detection of cytological changes may be attributed to the low viral load in collected specimens, with a $90 \% \mathrm{CPE}$ on the $12^{\text {th }}-16^{\text {th }}$ day post infection. Alternating passaging in cell cultures could be a supporting factor to maximize the viral load, as on the $5^{\text {th }}$ passage, cytological changes could be detected within 2-4 days post viral infection showing a gradual increase in the mean viral infectivity titer relative to time with a $0.56 \log (10) / 24$ $\mathrm{hr}, 0.4 \log (10) / 24 \mathrm{hr}, 0.429 \log (10) / 24 \mathrm{hr}$ and $0.543 \log (10) / 24 \mathrm{hr}$ for the 4 isolates, respectively. Other researchers have noted that the infective varicella zoster virus can be isolated using cell cultures and a typical cytopathic effect (CPE) can be observed within 3 days to 3 weeks according to the viral load. ${ }^{(6,24,42,47)}$ These results showed that Vero cells could be used successfully for isolation and propagation of VZV. In the mean time, identification of the viral isolates was carried out using immunofluorescent and immunodot blotting assays, with positive results for the 4 isolates. These results are supported by the Rawlinson et al. ${ }^{(48)}$ and Meqdam et al. ${ }^{(49)}$ who reported no positive viral culture for VZV had negative immunofluorescence. Also, antibodies to VZV could be detected using the same assay according to Leonardi et al. who reported that dot-ELISA could be used reliably for the detection of antibodies to varicella viruses in human sera. ${ }^{(50)}$

The cytotoxicity of liquorice powder extract and acyclovir to Vero cells was monitored by crystal violet uptake assay in order to determine the nontoxic concentrations that maintained $100 \%$ cellular viability. The antiviral activities of liquorice powder extract containing glycyrrhizin, acyclovir and interferon alpha 2a against one isolate were evaluated. The nontoxic concentration of liquorice extract containing glycyrrhizin $(125 \mu \mathrm{g} / \mathrm{ml})$ showed slight antiviral activity with a decrease in the mean viral infectivity titer by $0.5 \log (10) / 0.1 \mathrm{ml}$. Glycyrrhizin shows a more pronounced anti-VZV activity in human fibroblasts. ${ }^{(51,52)}$ The discrepancy in this study might be simply explained by the use of a powder extract of liquorice (containing glycyrrhizin as $125 \mu \mathrm{g} / \mathrm{ml}$ ) rather than the pure form of glycyrrhizin.

The nontoxic concentration of acyclovir (250 $\mu \mathrm{g} / \mathrm{ml}$ ) showed good antiviral activity against the isolated virus.The mean depletion of the viral infectivity titer was $4 \operatorname{logs}$ and the $\mathrm{IC}_{50}$ of acyclovir was reached at $7.8 \mu \mathrm{g} / \mathrm{ml}$. In that context, Wutzler ${ }^{(38)}$ reported that the $\mathrm{IC}_{50}$ for acyclovir against most laboratory strains and clinical isolates of VZV ranges from 0.12 to $10.8 \mu \mathrm{g} / \mathrm{ml}$. On the other hand, interferon alpha-2a showed the highest antiviral activity against VZV. Cells treated with $10 \mathrm{ng} / \mathrm{ml}$ interferon showed a complete suppression of virus infectivity titer. The antiviral activity of interferon-alpha against VZV in vivo has been demonstrated previously. ${ }^{(53)}$ Muller-Doblies et al. reported that interferon which was released from virus-infected cells activated $\mathrm{Mx}$ genes to produce Mx proteins that exhibited an antiviral effect by interfering with the viral replication cycle. ${ }^{(54)}$

\section{Conclusion}

VZV isolates were successfully isolated and propagated using Vero cells. Isolates were identified using indirect immunofluorescent and immunodot blotting techniques. Growth kinetics of the isolates revealed an increase in the viral infectivity titer relative to time. The cytotoxicity of liquorice powder extract and acyclovir on Vero cells was determined using crystal violet uptake assays. Glycyrrhizin in the crude form has a low antiviral activity against VZV compared with acyclovir and interferon. Molecular biology techniques are recommended for genotyping of Egyptian isolates. Screening of the antiviral activity of a wide range of herbal antiviral agents is also suggested in order to establish a safer, more economical and more efficient treatment, particularly for acyclovir resistant isolates.

\section{Acknowledgements}

The authors would like to thank The Holding 
Company for Biological Products and Vaccines (VACSERA), Cairo, Egypt, the Biology Dept, Faculty of Science, King Khalid University, Abha, Saudi Arabia and the National Organization for Research and Control of Biologicals, Cairo, Egypt for supporting this work.

\section{REFERENCES}

1. Yaghoobi M, Sadeghi-Zadeh M, Naderi-Manesh H, Noori-Daloii M. Varicella Zoster Virus (VZV) origindependent plasmid replication in the presence of the four overlapping cosmids comprising the complete genome of VZV. J Sciences 2004;15:21-6.

2. Kaushik KS, Lahiri KK, Chumber SK, Gupta RM, Kumar S, Kapila K, Karade S. Molecular characterization of clinical varicella-zoster strains from India and differentiation from the oka vaccine strain. Jpn J Infect Dis 2008;61:657.

3. Lopez AS, Marin M. Strategies for the control and investigation of varicella outbreaks Manual, 2008. Centers for Disease Control and Prevention. Available from: www.cdc.gov.chickenpox/outbreaks/manual.html.

4. Vonsover A, Leventon-Kriss S, Langer A, Smetana Z, Zaizov R, Potaznick D, Cohen IJ, Gotlieb-Stematsky T. Detection of varicella-zoster virus in lymphocytes by DNA hybridization. J Med Virol 1987;21:57-66.

5. Connie RM, George M. Laboratory identification of significant isolates. Text book of Diagnostic Microbiology. 2nd ed. Philadelphia, USA: WB Saunders Co., 2000:8401.

6. Marin J, Kese D, Potocnik M, Rogl BM. Laboratory diagnosis of herpesviruses. Dermatovenerologica 2000;9:20-5.

7. In: Winn W Jr, Allen S, Janda W, Koneman E, Procop G, Schreackenberger P, Woods G, eds. Koneman's Colour Atlas and Textbook of Diagnostic Microbiology. 6th ed. Philadelphia: Lippincott Williams and Wilkins, 2006:859940.

8. Gross G, Doerr H. Herpes Zoster: Recent Aspects of Diagnosis and Control. New York: Karger Publishers, 2006:15-8.

9. Breuer J, Whitley R. Varicella zoster virus: natural history and current therapies of varicella and herpes zoster. Herpes 2007;14 suppl 2:25-9.

10. Arvin AM. Varicella-zoster virus. Clin Microbiol Rev 1996;9:361-81.

11. Saint-Leger E, Caumes E, Breton G, Douard D, Saiag P, Huraux JM, Bricaire F, Agut H, Fillet AM. Clinical and virologic characterization of acyclovir-resistant varicellazoster viruses isolated from 11 patients with acquired immunodeficiency syndrome. Clin Infect Dis 2001;33: 2061-7.

12. Aoki F, Nakagawa K, Tanaka A, Matsuzaki K, Arai N,
Mae T. Determination of glabridin in human plasma by solid-phase extraction and LC-MS/MS. J Chromatogr B Analyt Technol Biomed Life Sci 2005;828:70-4.

13. Fukai T, Satoh K, Nomura T, Sakagami H. Preliminary evaluation of antinephritis and radical scavenging activities of glabridin from Glycyrrhiza glabra. Fitoterapia 2003;74:624-9.

14. Biondi DM, Rocco C, Ruberto G. Dihydrostilbene derivatives from Glycyrrhiza glabra leaves. J Nat Prod 2005;68:1099-102.

15. Cherng JM, Lin HJ, Hung MS, Lin YR, Chan MH, Lin JC. Inhibition of nuclear factor kappaB is associated with neuroprotective effects of glycyrrhizic acid on glutamateinduced excitotoxicity in primary neurons. Eur J Pharmacol 2006;547:10-21.

16. Zhang Q, Ye M. Chemical analysis of the Chinese herbal medicine Gan-Cao (licorice). J Chromatogr A 2009;1216: 1954-69.

17. Acharya SK, Dasarathy S, Tandon A, Joshi YK, Tandon BN. A preliminary open trial on interferon stimulator (SNMC) derived from Glycyrrhiza glabra in the treatment of subacute hepatic failure. Indian J Med Res 1993;98:6974.

18. Tanahashi T, Mune T, Morita H, Tanahashi H, Isomura Y, Suwa T, Daido H, Gomez-Sanchez CE, Yasuda K. Glycyrrhizic acid suppresses type 211 beta-hydroxysteroid dehydrogenase expression in vivo. J Steroid Biochem Mol Biol 2002;80:441-7.

19. Fujisawa Y, Sakamoto M, Matsushita M, Fujita T, Nishioka K. Glycyrrhizin inhibits the lytic pathway of complement-possible mechanism of its anti-inflammatory effect on liver cells in viral hepatitis. Microbiol Immunol 2000;44:799-804.

20. Ito A, Hayashi N, Katayama K, Hagiwara H, Kasahara A, Kashiwagi T, Yoshihara H, Fusamoto H, Kamada T. Effect of glycyrrhizin on viral replication and quasispecies in patients with type $\mathrm{C}$ chronic hepatitis. Int Hepatol Commun 1997;6:233-8.

21. Cinatl J, Morgenstern B, Bauer G Chandra P, Rabenau H, Doerr HW. Glycyrrhizin, an active component of liquorice roots, and replication of SARS-associated coronavirus. Lancet 2003;361:2045-6.

22. Fu B, Liu J, Li H, Li L, Lee FS, Wang X. The application of macroporous resins in the separation of licorice flavonoids and glycyrrhizic acid. J Chromatogr A 2005;1089:18-24.

23. Joseph LW, Thomas HW. Varicella-zoster virus. Diagnostic procedures for viral, rickettsial and chlamydial infections. 6th ed. American Public Health Association, 1994:379-406.

24. Arvin AM. Varicella-zoster virus. In: Knipe DM, Howley PM, eds. Fields Virology, Vol 2. 4th ed. Philadelphia, Pa: Lippincott Williams \& Wilkins, 2001:2731-67.

25. Abed El-Gaied HA, Hashem A, El-tayeb O, Mohamed AF. Evaluation of Inactivation efficacy of Sabin polio 
virus using different inactivating agents and its related immunogenicity post nano and microcappsulation. JMM 2010;1:114-22.

26. Takasuka N, Fujii H, Takahashi Y, Kasai M, Morikawa S, Itamura S, Ishii K, Sakaguchi M, Ohnishi K, Ohshima M, Hashimoto S, Odagiri T, Tashiro M, Yoshikura H, Takemori T, Tsunetsugu-Yokota Y. A subcutaneously injected UV-inactivated SARS coronavirus vaccine elicits systemic humoral immunity in mice. Int Immunol 2004;16:1423-30.

27. Schutzbank T, Robyn M. Immunofluorescence. In: Specter S, Hodinka RL, Young SA, eds. Clinical Virology Manual, 3rd ed. Washington, DC: ASM Press, 2000:7788.

28. Abendroth A, Morrow G, Cunningham AL, Slobedman B. Varicella-zoster virus infection of human dendritic dells and transmission to T Cells: implications for virus dissemination in the host. J Virol 2001;75:6183-92.

29. Kaufmann SH, Ewing CM, Shaper JH. The erasable Western blot. Anal Biochem 1987;161:89-95.

30. Steven S, Richard LH, Stephen AY. Laboratory Procedures. In: Specter S, Hodinka RL, Young SA, eds. Clinical Virology Manual. 3rd ed. Washington, DC: ASM Press, 2000:69-152.

31. Reed LJ, Muench H. A simple method of estimating fifty percent endpoints. Am J Hygiene 1928;27:493-7.

32. Grose C, Brunel PA. Varicella-zoster virus: isolation and propagation in human melanoma cells at 36 and 32 degrees C. Infect Immun 1978;19:199-203.

33. Finter NB. Dye uptake methods for assessing viral cytopathogenicity and their application to interferon assays. J Gen virol 1969;5:419-27.

34. Vijayan P, Raghu C, Ashok G, Dhanaraj SA, Suresh B. Antiviral activity of medicinal plants of Nilgiris. Indian J Med Res 2004;120:24-9.

35. Taylor JL, Casey MS, O'Brien WJ. Synergistic antiherpes virus activity of acyclovir and interferon in human corneal stromal cells. Invest Ophthalmol Vis Sci 1990;30:365-70.

36. Shin HJ, Cho MS, Jung SY, Kim HI, Im KI. In vitro cytotoxicity of Acanthamoeba spp. isolated from contact lens containers in Korea by crystal violet staining and LDH release assay. Korean J Parasitol 2000;38:99-102.

37. Harada $S$. The broad anti-viral agent glycyrrhizin directly modulates the fluidity of plasma membrane and HIV-1 envelope. Biochem J 2005; 392(Pt 1):191-9.

38. Wutzler P. Antiviral therapy of herpes simplex and varicella-zoster virus infections. Intervirology 1997;40:34356.

39. Weller TH. Varicella-herpes zoster virus. Viral Infections of Humans: Epidemiology and Control. In: Evans AS, Kaslow RA, eds. Viral Infections of Humans: Epidemiology and Control. New York: Plenum Press, 1997:865-92.

40. Loparev V, Martro E, Rubtcova E, Rodrigo C, Piette JC, Caumes E, Vernant JP, Schmid DS, Fillet AM. Toward universal varicella-zoster virus (VZV) genotyping: diversity of VZV strains from France and Spain. J Clin Microbiol 2007;45:559-63.

41. Ozaki T, Ichikawa T, Matsui Y, Kondo H, Nagai T, Asano Y, Yamanishi K, Takahashi M. Lymphocyte-associated viremia in varicella. J Med Virol 1986;19:249-53.

42. Schmutzhard J, Merete Riedel H, Zweygberg Wirgart B, Grillner L. Detection of herpes simplex virus type 1, herpes simplex virus type 2 and varicella-zoster virus in skin lesions. Comparison of real-time PCR, nested PCR and virus isolation. J Clin Virol 2004;29:120-6.

43. Gerna G, Chambers RW. Varicella-zoster plaque assay and plaque reduction neutralization test by the immunoperoxidase technique. J Clin Microbiol 1976;4: 437-42.

44. O’Neill HJ, Russell JD, Wyatt DE, McCaughey C, Coyle $\mathrm{PV}$. Isolation of viruses from clinical specimens in microtitre plates with cells inoculated in suspension. J Virol Methods 1996;62:169-78.

45. Levin MJ, Leventhal S, Masters HA. Factors influencing quantitative isolation of varicella-zoster virus. J Clin Microbiol 1984;19:880-3.

46. Ozaki T, Kajita Y, Namazue J, Yamanishi K. Isolation of varicella-zoster virus from vesicles in children with varicella. J Med Virol 1996;48:326-8.

47. Moretti F, Uberti-Foppa C, Quiros-Roldan E, Fanti L, Lillo F, Lazzarin A. Oesophagobronchial fistula caused by varicella zoster virus in a patient with AIDS: a unique case. J Clin Pathol 2002;55:397-8.

48. Rawlinson WD, Dwyer DE, Gibbons VL, Cunningham AL. Rapid diagnosis of varicella-zoster virus infection with a monoclonal antibody based direct immunofluorescence technique. J Virol Methods 1989;23:13-8.

49. Meqdam MM, Todd D, Al-Abosi M. Detection of herpes simplex and varicella-zoster viruses in clinical specimens using direct immunofluorescence and cell culture assays. Microbios 2001;105:111-8.

50. Leonardi MS, Gazzara D, Zummo S, Fattal-German M, Bizzini B, Mastroeni P. A dot-ELISA for the detection of $\mathrm{IgG}$ antibodies to mumps and varicella viruses. J Clin Lab Anal 1990;4:165-9.

51. Baba M, Shigeta S. Antivrial activity of glycrrhizin against varicella-zoster virus in vitro. Antiviral Res 1990;7:99-107.

52. Yarnell E, Abascal K. Herbs for treating Herpes Zoster infections. Alternative and Complementary Therapies 2005; $11: 131-4$

53. Chia-Chi K, Anne S, Arvin A. The anti-viral effects of interferon- $\alpha$ on varicella-zoster virus (VZV). Clinical Immunology 2006;119:181-3.

54. Muller-Doblies D, Ackermann M, Metzler A. In vitro and in vivo detection of $\mathrm{Mx}$ gene products in bovine cells following stimulation with alpha/beta interferon and viruses. Clin Diagn Lab Immunol 2002;9:1192-9. 